\title{
Growth after renal transplantation
}

\author{
Jérôme Harambat • Pierre Cochat
}

Received: 31 August 2007 /Revised: 30 January 2008 / Accepted: 1 February 2008 / Published online: 26 March 2008

(C) IPNA 2008

\begin{abstract}
Growth may be severely impaired in children with chronic renal insufficiency. Since short stature can have major consequences on quality of life and self-esteem, achieving a 'normal' height is a crucial issue for renal transplant recipients. However, despite successful renal transplantation, the final height attained by most recipients is not the calculated target height. Catch-up growth spurts post-transplantation are usually insufficient to compensate for the retardation in growth that has occurred during the pretransplant period. Longitudinal growth post-transplantation is therefore influenced by the age at transplantation but also by subsequent allograft function and steroid exposure, both of which interfere with the growth hormone/insulin-like growth factor axis. The management of growth retardation in renal transplant recipients includes adequate nutritional intake, correction of metabolic acidosis, prevention of bone disease, steroid-sparing strategies and a supraphysiological dose of recombinant human growth hormone in selected cases.
\end{abstract}

Keywords Children · Corticosteroids · Growth · Growth hormone $\cdot$ Quality of life $\cdot$ Renal transplantation

\section{Introduction}

One of the goals of renal transplantation in children is to restore an optimal quality of life (QOL), including the

J. Harambat $\cdot$ P. Cochat

Département de Pédiatrie and Inserm U820,

Hôpital Edouard-Herriot and Université Claude-Bernard Lyon 1,

Lyon, France

P. Cochat $(\square)$

Département de Pédiatrie, Unité de Néphrologie Pédiatrique, Hôpital Edouard Herriot,

place d'Arsonval,

69437 Lyon, France

e-mail: pierre.cochat@chu-lyon.fr optimization of final height. However, catch-up growth post-transplantation is generally not sufficient to compensate for the deficit that has been acquired during the pretransplant period. Growth retardation post-transplantation is multifactorial and associated with impaired medical and psychosocial outcomes. Despite numerous recent developments in pediatric renal transplantation, achieving an adequate final height remains a challenging issue for such recipients.

\section{Growth assessment}

Growth assessment and management should be performed in any pediatric transplant recipient [1]. Anthropometric parameters, including height, body weight, body mass index (plus head circumference in children less than 3 years of age), should be monitored every 3 months in children less than 3 years of age, then every 6 months until final height is reached. Final height is reached as the growth velocity per year minus $1-2 \mathrm{~cm}$ after puberty has occurred. The target height $(\mathrm{H}$, in $\mathrm{cm})$ is based on mid-parental height (girls $=\left[\mathrm{H}_{\text {mother }}+\mathrm{H}_{\text {father }}-13\right] / 2$; boys $=\left[\mathrm{H}_{\text {mother }}+\mathrm{H}_{\text {father }}+\right.$ 13]/2) according to Tanner method [2]. A more recent formula based on parental height standard deviation score (SDS) and independent of sex has been proposed [3]. Growth parameters should be plotted on growth charts using either SDS or centiles adapted to gender and local standard measurements.

\section{Growth features post-transplantation}

Magnitude of growth impairment post-transplantation

Data from the North American Pediatric Renal Trials and Collaborative Studies (NAPRTCS) 2006 annual 
report reported that the mean height SDS was -1.4 in a cohort of over 1500 patients aged 19 years or more [4], with $25 \%$ of these patients having a height SDS of -2.3 or worse and $10 \%$ being below -3.3 SDS. During the last 10 years, single center reports have specifically addressed the issue of final height after renal transplantation in childhood [5-10]. The percentage of patients who achieved a normal final height (height $\operatorname{SDS} \geq-1.88$, i.e. third centile) ranged from 42 to $75 \%$ (Table 1) which is higher than the that reported in previous studies in which $62-77 \%$ of patients exhibited growth failure at 18 years of age or more $[11,12]$.

Impact of growth failure post-transplantation

Growth delay post-transplantation may be associated with a worse medical outcome. Furth et al. [13] showed that children with end stage renal disease (ESRD) and moderate $(-2>$ SDS $>-3)$ or severe $(<-3$ SDS $)$ growth retardation had a significantly higher risk of death and hospitalization, even after adjustment for treatment modalities (dialysis or transplant). Such events were mainly attributed to infectious diseases, suggesting that growth failure might be a marker of poor nutritional status, a known risk factor for infectious complications.

Growth failure may also have an impact on psychological and social development, self-esteem and QOL. Behavioral and cognitive disorders, including immaturity, inhibition, anxiety, attention deficits and learning disability, have been reported in children with short stature $[14,15]$. Such difficulties were attributed to family overprotection and negative social experience related to the child's short stature, leading to impaired emotional and social development. Experience in patients with growth hormone deficiency or idiopathic short stature has shown that the use of recombinant human growth hormone (rhGH) improves behavior disturbances [16]. In adults who were transplanted during childhood, short stature has been associated with a lower marital status, a lower level of education and a lower level of employment [17]. Moreover, Rosenkranz et al. reported that more than onethird of adults with childhood-onset ESRD were dissatisfied with their body height [18]. Positive perception of QOL significantly correlated with satisfaction with adult height.

\section{Factors influencing growth post-transplantation}

Growth after transplantation is mainly affected by the degree of pre-transplantation growth deficit, age at transplantation, graft function and exposure to glucocorticoids.

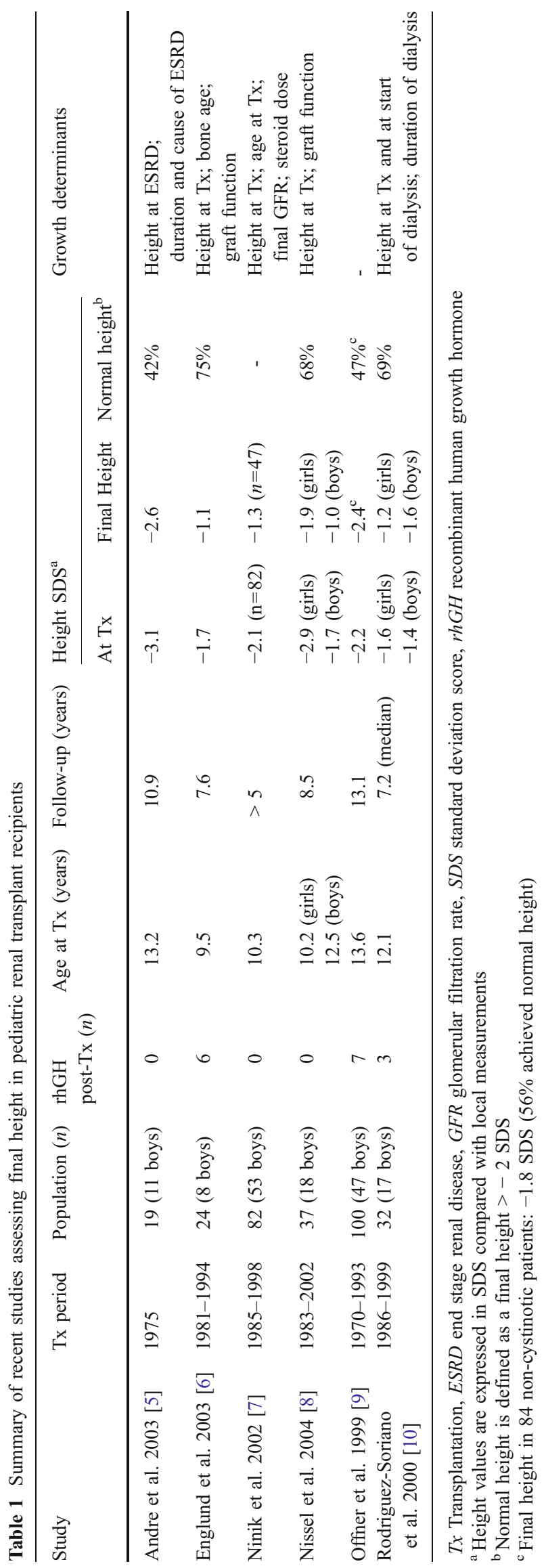


Pre-transplantation growth

Growth failure is a common feature in children with chronic renal insufficiency (CRI). Growth determinants during the pre-transplant period may include age at diagnosis of CRI, nutritional intake, primary disease, tubular impairment, renal osteodystrophy, hormonal disorders and pre-transplantation use of steroids. Two periods are at particular risk of impaired growth velocity: infancy and puberty [19, 20]. Height velocity generally decreases when the glomerular filtration rate (GFR) is below $30 \mathrm{~mL} / \mathrm{min}$ per $1.73 \mathrm{~m}^{2}$ [21]. However, there is evidence that growth impairment begins earlier. Indeed, in a subset of the NAPRTCS registry [4] that includes 1901 patients with moderate CRI (estimated GFR between 50 and $75 \mathrm{~mL} / \mathrm{min}$ per $1.73 \mathrm{~m}^{2}$ ), $21.5 \%$ had standardized height measurement below the third centile (height SDS $\leq-1.88$ ) and in 2477 children with an estimated GFR of $25-50 \mathrm{~mL} / \mathrm{min}$ per $1.73 \mathrm{~m}^{2}, 36.8 \%$ had a height SDS of less than -1.88 . Children enrolled in this registry are growth impaired at initiation of dialysis and exhibit a deceleration of growth during the following 6,12 or 24 months-with the exception of children aged 0-1 years. At the time of transplantation, the mean height SDS measured in 8659 children was -1.86 for boys and -1.72 for girls [4].

Pre-transplantation growth impairment may be reduced by adequate conservative treatment of CRI, including aggressive nutritional support during infancy and early childhood [22] and treatment with rhGH when indicated [23]. This has resulted in a significant improvement of pretransplantation growth; data from the NAPRTCS [4] has shown that height SDS at the time of initial transplant has improved from a mean of -2.4 in 1987 to -1.5 in the 2000 and 2003 cohorts.

\section{Role of age at transplantation}

In the NAPRTCS 2006 report [4], only infants and pre-school age children (2-5 years) exhibited catch-up growth posttransplantation (Fig. 1). However catch-up growth occurred mainly during the first 2 years post-transplantation, with no further improvement being observed thereafter; preschoolaged children who had the greatest deficit at transplant ( -2.26 SDS) exhibited the best growth improvement of 0.5 SDS. Conversely, school age children (6-12 years), and adolescents demonstrated either no improvement or even a decrease in height SDS (Fig. 1). The prepubertal growth deceleration that occurs in the normal population is prolonged after transplantation, and puberty and bone age are usually delayed [8, 12]. This means that growth continues for longer than normal but height gain is rarely as much as expected due to loss of height potential [8, 24]. However, some authors have reported that significant catch-

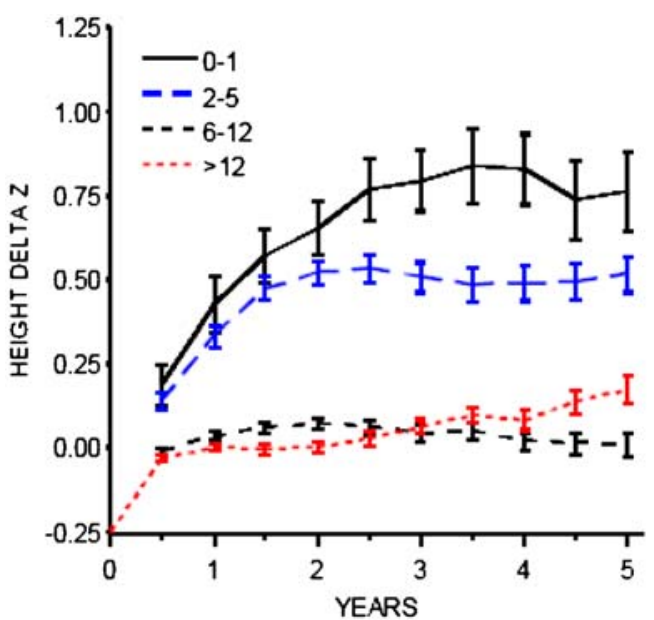

Fig. 1 Mean changes $( \pm$ SE) from baseline in height standard deviation score (SDS) by age at transplant (data from the NAPRTCS 2006 annual report)

up growth can occur after transplantation even in children of pubertal age [25]; the authors speculated that catch-up growth may be related to the early use of a low-dose and alternate-day steroid regimen.

\section{Effect of graft function}

The effect of a reduced GFR on growth has been known for a long time [26]. A report from the NAPRTCS that assessed final adult height in 237 subjects who received a transplant before 11 (girls) or 12 (boys) years of age showed that a decreased GFR was an independent predictor of reduced final height [27]. Guest et al. reported that prepubertal children with a serum creatinine level above $120 \mu \mathrm{mol} / \mathrm{L}$ did not exhibit catch-up growth during the first year posttransplantation [28]. More recently, Nissel et al. showed that prepubertal catch-up growth and total pubertal height gain correlated positively with GFR [8].

\section{Role of steroid therapy}

Since the introduction of steroid therapy more than 50 years ago, it became clear that daily and prolonged steroid administration leads to growth impairment [29]. Steroid therapy inhibits growth by both interfering with the hypothalamuspituitary/growth hormone/insulin-like growth factor axis and having a direct effect on bone formation (see below). Pharmacokinetic studies of methylprednisolone in pediatric liver and kidney transplant recipients have demonstrated that the area under the serum concentration-time curve (AUC) rather than dose was predictive for growth retardation [30, 31]. However, this correlation between AUC and growth was not unanimously found in transplanted children treated with prednisone or prednisolone [32]. 
Other factors

Many other factors may contribute to post-transplant growth retardation.

Donor type Pape et al. identified 51 boys who received a renal transplant (30 deceased donors and 21 living related donors) before the rhGH era, who were followed for at least 5 years [33]. Children who received a living donor graft had a significantly greater height SDS and growth velocity during the first 5 years post-transplantation than those who received a graft from a deceased donor. Interestingly, this difference remained significant after adjustment for potential confounders, including GFR. In the latest NAPRTCS report, donor source seemed to predict height SDS changes 2 years post-transplantation, but the mean difference was less than 0.3 SDS [2].

Pre-emptive transplantation As dialysis is associated with decreased growth velocity, pre-emptive renal transplantation may optimize final height. Some authors reported better height SDS in the first years post-transplantation in those children who received a pre-emptive renal transplant compared to those with dialysis prior to transplantation [6, $25]$.

Race A previous NAPRTCS report suggested that race may also have an impact on growth following transplantation [34]. The change in height SDS was negative in AfricanAmerican and Hispanic recipients but positive in Caucasians. However, race did not significantly influence growth in multivariate analysis.

\section{Pathophysiology of growth impairment post-transplantation}

Disturbances in the growth hormone/insulin-like growth factor axis

In humans, longitudinal bone growth is achieved primarily by endochondral ossification, and an intact function of the somatotropic hormone axis is essential for normal growth. In healthy individuals, growth hormone $(\mathrm{GH})$ is secreted by the pituitary gland in a pulsatile pattern; such a mechanism is regulated by $\mathrm{GH}$ releasing hormone $(\mathrm{GHRH}), \mathrm{GH}$ release inhibiting hormone $(\mathrm{GHRIH})$ and other feedback regulator agents. Growth hormone acts on the liver and other tissues, where it stimulates the synthesis of insulin-like growth factor-1 (IGF-1) and its binding proteins (IGFBP). Circulating free IGF-1 stimulates the proliferation of chondrocytes in the growth plate [35]. The
IGFBPs, in turn, modulate IGF-1 activity, mostly by an inhibitory action mediated by IGFBP-3. Growth impairment in renal transplant recipients is multifactorial, and the somatotropic axis may be disturbed by several complex mechanisms.

Glucocorticoids are known to interfere with the $\mathrm{GH} /$ IGF axis by inducing down-regulation of $\mathrm{GH}$ receptors and inhibition of IGF-1 synthesis [36] and by modifying the equilibrium among IGFBP subtypes [37]. However, exogenous GH may reverse the catabolic and growthdepressing effects of glucocorticoids [38, 39]. In addition, glucocorticoid treatment directly affects growth plate function by suppressing chondrocyte proliferation, reducing bone formation and altering endochondral ossification [40, 41].

Impaired renal function in transplant recipients per se also contributes to growth disturbance so that even a minimal graft dysfunction may be associated with growth retardation [42]. Due to both decreased metabolic clearance and altered release pattern, $\mathrm{GH}$ concentration is normal or elevated in any child with CRI $[43,44]$ so that such patients exhibit a resistance profile to $\mathrm{GH}$ action. Indeed, it has been shown that uremia results in reduced $\mathrm{GH}$ receptor density and in a defect of intracellular $\mathrm{GH}$ receptor signal transduction, so that IGF-1 transcription is decreased [45]. Furthermore, modifications in IGFBPs levels limit the bioavailability of free IGF-1 [46, 47].

\section{Metabolic acidosis}

The presence of metabolic acidosis may additionally affect growth through a reduction of GH and IGF-1 secretion [48] as well as by $\mathrm{GH}$ resistance [49]. This phenomenon is attributable to a down-regulation of hepatic IGF-1 and GH receptor expression and increased expression of IGFBP-2 and -4 , both of which inhibit the effects of IGF-1 [50]. In addition, metabolic acidosis has been shown to have an inhibitory effect on cartilage cell progression and endochondral bone formation in experimental studies [51]. It also leads to reduced albumin synthesis, increased calcium efflux from bone and protein degradation. However, there is no evidence that a correction of metabolic acidosis will have a beneficial effect on growth posttransplantation.

\section{Secondary hyperparathyroidism}

Long-term secondary hyperparathyroidism may persist after renal transplantation [52] and have a negative impact on bone turnover and growth plate function [48]; this may be attributable to abnormal epiphyseal growth plate due to reduced PTH/PTHrP (PTH-related peptide) receptor and type $\mathrm{X}$ collagen expression. A potential benefit of treating for 
secondary hyperparathyroidism is an improvement in linear growth, although there is no strong evidence supporting this.

\section{Nutrition}

Independently of the above mechanisms, proteinocaloric deficit and subsequent malnutrition result in growth retardation, mainly in infants and young children. Indeed, protein restriction leads to a resistance to $\mathrm{GH}$ action at the hepatic level, an increase in IGF-1 clearance rate and, consequently, a reduction of IGF-1 levels [53-55].

\section{Sex hormones}

Disturbances of the gonadotropic axis may contribute to altered growth patterns, with a delay and a shorter duration in the pubertal growth spurt $[8,12,56]$.

\section{Management of growth post-transplantation}

\section{Conservative strategies}

Growth velocity can be improved by conservative approaches, including adequate nutritional intake, correction of metabolic disorders, prevention of renal osteodystrophy and steroid-sparing protocols (Table 2). The use of alternate-day steroids in kidney transplantation was first described in the 1970s [57], and several studies carried out subsequently have demonstrated an improvement in growth in patients on daily low or alternate-day steroid therapy [58, 59]. The use of deflazacort, a synthetic glucocorticoid derived from prednisolone, has led to improved growth velocity with a comparable immunosuppressive effect [60], but there are few data on this drug because of its limited availability. Encouraging results have been reported with steroid avoidance or early withdrawal protocols [61-64], but additional evidence is expected from ongoing trials.

Growth hormone therapy

\section{Efficacy and safety}

The rationales for the use of rhGH in short children with renal transplants are: (1) exogenous GH can be considered to be a substitutive therapy in children with glucocorticoidinduced GH hyposecretion and (2) rhGH may restore IGF bioactivity in those with normal GH secretion but decreased IGF bioavailability $[65,66]$. Four randomized controlled trials have been conducted to evaluate the safety and efficacy of rhGH after renal transplantation [67-70]. All four studies have shown a significant improvement in growth velocity in the treated group compared to the
Table 2 Conservative methods to optimize growth velocity posttransplantation $[1,87]$

\begin{tabular}{|c|c|}
\hline $\begin{array}{l}\text { Causes of growth } \\
\text { impairment }\end{array}$ & Methods \\
\hline Reduced GFR & $\begin{array}{l}\text { Prevention and management of chronic } \\
\text { allograft nephropathy } \\
\text { Treatment of acute rejection episodes } \\
\text { Drug compliance }\end{array}$ \\
\hline Steroid therapy & $\begin{array}{l}\text { Daily low or alternate day steroid therapy } \\
\text { Steroid avoidance/withdrawal under evaluation }\end{array}$ \\
\hline Bone disease & $\begin{array}{l}\text { Target PTH within normal range in CKD stage } \\
2-3 \text { and }<2 \times \text { upper limit in CKD stage } 4 \\
\text { Target plasma phosphate within age-appropriate } \\
\text { normal range }\end{array}$ \\
\hline Metabolic acidosis & Target plasma bicarbonate $>22 \mathrm{mmol} / \mathrm{L}$ \\
\hline Malnutrition & Adequate nutritional intake \\
\hline Comorbidities & $\begin{array}{l}\text { Assessment and control of comorbidities which } \\
\text { may impair growth (chronic inflammation, } \\
\text { liver, lung or heart diseases) }\end{array}$ \\
\hline
\end{tabular}

PTH Parathyroid hormone; $C K D$ chronic kidney disease

controls (Table 3), but none of these trials has remained controlled for more than 1 year. Although previous observations have suggested an increased risk of acute rejection [71] and controversial effects on GFR [72, 73], none of the randomized controlled trials have demonstrated an increased incidence of acute rejection or a change in GFR. However, two of them found that a history of two or more acute rejection episodes before the initiation of rhGH was predictive of a subsequent rejection episode following the initiation of rhGH therapy $[69,70]$. More recently, a non-randomized study from the NAPRTCS compared 513 rhGH-treated transplant recipients to 2263 untreated children over a 5-year period [74]. The authors concluded that children younger than 10 years of age grew better than older ones; the final height was superior in the rhGHtreated group (mean cumulative increase of $3.6 \mathrm{~cm}$ ), without any significant change in allograft function and graft failure rate, and the incidence of adverse events was similar in both groups.

The immune system may be adversely affected by the GH-induced stimulation of cytotoxic T cells in vitro [75]. However, data in pediatric renal transplant recipients suggest either a transient or a moderate impact of rhGH on the immune system [76, 77].

A major concern with the use of rhGH is the potential risk of malignancy. There is no evidence of increased risk of lymphoproliferative disease with the use of rhGH posttransplant only. However, a significant association has been found between the use of rhGH during the pre-transplant period and the development of post-transplant lymphopro- 


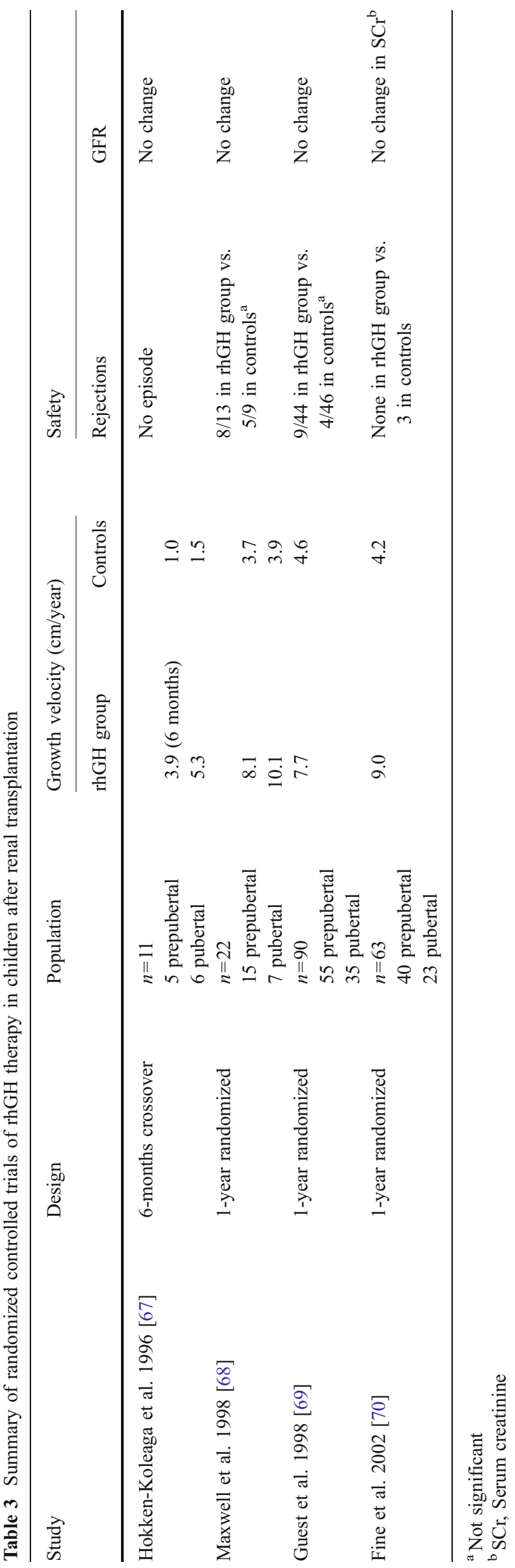

liferative disease [78]. Tydén et al. reported the development of renal cancer in the transplant kidneys of two adolescents treated with rhGH [79]. However, an analysis of data from companies commercializing rhGH was unable to identify rhGH as a risk factor for post-transplant renal cancer [80].

Other side effects have been reported under rhGH therapy, but they do not represent a significant risk and should not limit the current use of rhGH in growth-retarded transplanted children. Several studies have shown a transient elevation of glucose and insulin secretion in rhGH-treated patients with CRI or after renal transplantation [81]. There has been no report of diabetes mellitus development under rhGH, but one patient with cystinosis has been reported. Recombinant human growth hormone has also been found to induce an increase in lipoprotein(a) serum concentration without a significant change in cholesterol or triglycerides serum concentrations [82]. This increase did not persist over time after a long-lasting treatment with rhGH in patients with Turner syndrome [83]. Transient increases in alkaline phosphatase activity, serum phosphate concentration [70] or even PTH concentration [68] have been observed in randomized controlled trials, but rhGH did not induce an increased incidence of renal osteodystrophy; however, overt renal osteodystrophy may blunt the response to rhGH [84].

In a retrospective survey, benign intracranial hypertension was detected in about $1 \%$ of 1670 children with CRI [85]. This complication may be exacerbated by the presence of fluid overload and arterial hypertension associated with CRI.

\section{Current recommendations}

The use of rhGH in growth-retarded renal transplant recipients has not been approved by North American or European drug regulatory agencies, so that there are no clear guidelines for its use in such patients. In addition, the American Association of Clinical Endocrinologists does not recommend the use of rhGH after renal transplantation, unless it is given as a part of a research study [86]. However, based on published trials and registries, a recent report from the Kidney Foundation on Kidney Disease Improving Global Outcomes (KDIGO) has provided recommendations for its use after pediatric renal transplantation [1]. All growth parameters should be assessed and corrected before $\mathrm{rhGH}$ is initiated. Therapy with $\mathrm{RhGH}$ can be started when height falls below the third centile for age and sex. It remains uncertain whether GH therapy should be considered in children with still-normal relative height but low growth velocity. The recommended dose is $0.05 \mathrm{mg} / \mathrm{kg}$ per day $\left(1.4 \mathrm{mg} / \mathrm{m}^{2}\right.$ per day $)$ in prepubertal children. In pediatric transplant patients with chronic 
kidney disease stages $2-4$, bone disease should be managed according to K/DOQI guidelines [87]. A practical approach for the use of rhGH after transplantation is proposed in Table 4.

In summary, steroid-sparing/avoidance may be the firstline management of short transplant children with a good GFR (i.e. $>60 \mathrm{~mL} / \mathrm{min}$ per $1.73 \mathrm{~m}^{2}$ ), whereas $\mathrm{rhGH}$ treatment may be proposed to those short patients with either impaired GFR (i.e. $<60 \mathrm{~mL} / \mathrm{min}$ per $1.73 \mathrm{~m}^{2}$ ) or the failure of steroid-sparing/avoidance despite a good GFR.

\section{Conclusion}

Optimal growth is a major issue regarding post-transplantation quality of life and self esteem in children. The current

Table 4 Proposed recommendations for the use of rhGH in children with a renal transplant

\begin{tabular}{|c|c|}
\hline $\begin{array}{l}\text { Recombinant human growth } \\
\text { hormone therapy }\end{array}$ & $\begin{array}{l}\text { Factors to take into } \\
\text { consideration }\end{array}$ \\
\hline $\begin{array}{l}\text { Target population } \\
\text { for rhGH therapy }\end{array}$ & $\begin{array}{l}\text { Prepubertal children } \\
\text { Pubertal children? } \\
-2 \text { SDS for height } \\
\text { Poor growth velocity? } \\
\text { Growth potential documented } \\
\text { by open epiphyses } \\
\text { Correction of other factors } \\
\text { contributing to growth failure }\end{array}$ \\
\hline Contra-indication & Active malignancy \\
\hline Baseline evaluation & $\begin{array}{l}\text { Pubertal stage } \\
\text { Anthropometric assessment } \\
\text { Target height } \\
\text { Hip X-ray and bone age } \\
\text { Fundoscopic examination } \\
\text { Serum phosphate, calcium and PTH }\end{array}$ \\
\hline Optimal dose of rhGH & $0.05 \mathrm{mg} / \mathrm{kg}$ per day $\left(4 \mathrm{IU} / \mathrm{m}^{2}\right.$ per day) \\
\hline Mode of administration & Daily subcutaneous injection \\
\hline Follow-up evaluation & $\begin{array}{l}\text { Height, weight, growth velocity every } \\
3 \text { months } \\
\text { Close monitoring of graft function in } \\
\text { children with a history of acute } \\
\text { rejection } \\
\text { Serum calcium, phosphate and PTH } \\
\text { every } 3 \text { months } \\
\text { Bone age every year according } \\
\text { to growth profile }\end{array}$ \\
\hline rhGH discontinuation & $\begin{array}{l}\text { Achieved height endpoint } \\
\text { Closed epiphyses } \\
\text { Slipped femoral epiphyses } \\
\text { Severe hyperparathyroidism } \\
\text { Active malignancy } \\
\text { Documented benign intracranial } \\
\text { hypertension } \\
\text { Non compliance }\end{array}$ \\
\hline
\end{tabular}

final height of transplant patients has remained suboptimal, but recent strategies, including steroid-sparing/avoidance regimes, could further improve longitudinal growth in renal transplant children.

\section{Questions}

(Answers appear following the reference list)

1) What has been learned from epidemiological data about post-transplant growth?

a. Most renal transplant children attain target height

b. Growth velocity increases after 3 years posttransplantation

c. Height SDS at transplantation has improved over time

d. Catch-up growth is primarily exhibited by adolescents

e. Quality of life of transplant recipients is not influenced by height

2) Which factor positively influences growth post-transplantation?

a. Male gender

b. Young age at transplantation

c. Primary tubular disorder

d. Prolonged steroid therapy

e. Dialysis prior to transplantation

3) Which mechanism contributes to glucocorticoidsinduced growth retardation?

a. Decreased serum IGF-1 concentration

b. Reduced sensitivity to endogenous GH and IGF-1

c. Direct stimulation of chondrocytes proliferation

d. Decreased production of all IGFBPs

e. Disturbances in the gonadotropic hormone axis

4) How can growth potential be optimized?

a. Correction of metabolic acidosis

b. Adequate nutritional intake

c. Prevention of bone disease

d. Supraphysiological dose of $\mathrm{rhGH}$ when indicated

e. All of the above

5) Which of the following statements about the use of rhGH is correct?

a. The optimal dosage of $\mathrm{rhGH}$ is $0.02 \mathrm{mg} / \mathrm{kg}$ per day

b. There is evidence that rhGH improves final height

c. Randomized controlled trials with rhGH have shown an increased risk of acute rejection 
d. rhGH may induce an elevation of serum insulin concentration

e. rhGH has been identified as a risk factor for post transplantation malignancy

\section{References}

1. Abbud-Filho M, Adams PL, Alberu J, Cardella C, Chapman J, Cochat P, Cosio F, Danovitch G, Davis C, Gaston RS, Humar A, Hunsicker LG, Josephson MA, Kasiske B, Kirste G, Leichtman A, Munn S, Obrador GT, Tibell A, Wadström J, Zeier M, Delmonico FL (2007) A report of the Lisbon Conference on the care of the kidney transplant recipient. Transplantation 83: S1-22

2. Tanner JM, Goldstein H, Whitehouse RH (1970) Standards for children's height at ages 2-9 years allowing for heights of parents. Arch Dis Child 45:755-762

3. Hermanussen M, Cole J (2003) The calculation of target height reconsidered. Horm Res 59:180-183

4. North American Pediatric Renal Trials and Collaborative Studies (2006) Annual Report. Available at https://web.emmes.com/study/ ped/annlrept/annlrept2006.pdf. Accessed 1 June 2007

5. André JL, Bourquard R, Guillemin F, Krier MJ, Briançon S (2003) Final height in children with chronic renal failure who have not received growth hormone. Pediatr Nephrol 18:685691

6. Englund MS, Tydén G, Wikstad I, Berg UB (2003) Growth impairment at renal transplantation: a determinant of growth and final height. Pediatr Transplant 7:192-199

7. Ninik A, McTaggart SJ, Gulati S, Powell HR, Jones CL, Walker RG (2002) Factors influencing growth and final height after renal transplantation. Pediatr Transplant 6:219-223

8. Nissel R, Brazda I, Feneberg R, Wigger M, Greiner C, Querfeld U, Haffner D (2004) Effect of renal transplantation in childhood on longitudinal growth and adult height. Kidney Int 66:792800

9. Offner G, Latta K, Hoyer PF, Baum HJ, Ehrich JH, Pichlmayr R, Brodehl J (1999) Kidney transplanted children come of age. Kidney Int 55:1509-1517

10. Rodriguez-Soriano J, Vallo A, Quintela MJ, Malaga S, Loris C (2000) Predictors of final adult height after renal transplantation during childhood: a single-center study. Nephron 86:266273

11. Potter D, Feduska N, Melzer J, Garovoy M, Hopper S, Duca R, Salvatierra O Jr (1986) Twenty years of renal transplantation in children. Pediatrics 77:465-470

12. Hokken-Koelega AC, van Zaal MA, van Bergen W, de Ridder MA, Stijnen T, Wolff ED, de Jong RC, Donckerwolcke RA, de Muinck Keizer-Schrama SM, Drop SL (1994) Final height and its predictive factors after renal transplantation in childhood. Pediatr Res 36:323-328

13. Furth SL, Hwang W, Yang C, Neu AM, Fivush BA, Powe NR (2002) Growth failure, risk of hospitalization and death for children with end-stage renal disease. Pediatr Nephrol $17: 450-455$

14. Stabler B, Clopper RR, Siegel PT, Stoppani C, Compton PG, Underwood LE (1994) Academic achievement and psychological adjustment in short children. The National Cooperative Growth Study. J Dev Behav Pediatr 15:1-6

15. Qvist E, Jalanko H, Holmberg C (2003) Psychosocial adaptation after solid organ transplantation in children. Pediatr Clin North Am 50:1505-1519
16. Stabler B, Siegel PT, Clopper RR, Stoppani CE, Compton PG, Underwood LE (1998) Behavior change after growth hormone treatment of children with short stature. J Pediatr 133:366373

17. Broyer M, Le Bihan C, Charbit M, Guest G, Tête MJ, Gagnadoux MF, Niaudet P (2004) Long-term social outcome of children after kidney transplantation. Transplantation 77:1033-1037

18. Rosenkranz J, Reichwald-Klugger E, Oh J, Turzer M, Mehls O, Schaefer F (2005) Psychosocial rehabilitation and satisfaction with life in adults with childhood-onset of end-stage renal disease. Pediatr Nephrol 20:1288-1294

19. Rees L, Rigden SP, Ward GM (1989) Chronic renal failure and growth. Arch Dis Child 64:573-577

20. Schaefer F, Seidel C, Binding A, Gasser T, Largo RH, Prader A, Schärer K (1990) Pubertal growth in chronic renal failure. Pediatr Res 28:5-10

21. Kari JA, Gonzalez C, Ledermann SE, Shaw V, Rees L (2000) Outcome and growth of infants with severe chronic renal failure. Kidney Int 57:1681-1687

22. Schaefer F, Wingen AM, Hennicke M, Rigden S, Mehls O (1996) Growth charts for prepubertal children with chronic renal failure due to congenital renal disorders. European study group for nutritional treatment of chronic renal failure in childhood. Pediatr Nephrol 10:288-293

23. Haffner D, Schaefer F, Nissel R, Wühl E, Tönshoff B, Mehls O (2000) Effect of growth hormone treatment on the adult height of children with chronic renal failure. German study group for growth hormone treatment in chronic renal failure. N Engl J Med 343:923-930

24. Tejani A, Fine R, Alexander S, Harmon W, Stablein D (1993) Factors predictive of sustained growth in children after renal transplantation. The North American pediatric renal transplant cooperative study. J Pediatr 122:397-402

25. Maxwell H, Haffner D, Rees L (1998) Catch-up growth occurs after renal transplantation in children of pubertal age. J Pediatr $133: 435-440$

26. Pennisi AJ, Costin G, Phillips LS, Uittenbogaart C, Ettenger RB, Malekzadeh MH, Fine RN (1977) Linear growth in long-term renal allograft recipients. Clin Nephrol 8:415-421

27. Fine RN, Ho M, Tejani A, North American Pediatric Renal Transplant Cooperative Study (NAPRTCS) (2001) The contribution of renal transplantation to final adult height: a report of the North American Pediatric Renal Transplant Cooperative Study (NAPRTCS). Pediatr Nephrol 16:951-956

28. Guest G, Broyer M (1991) Growth after renal transplantation: correlation with immunosuppressive therapy. Pediatr Nephrol 5:143-146

29. Blodgett FM, Burgin L, Iezzoni D, Gribetz D, Talbot NB (1956) Effects of prolonged cortisone therapy on the statural growth, skeletal maturation and metabolic status of children. $\mathrm{N}$ Engl J Med 254:636-641

30. Sarna S, Hoppu K, Neuvonen PJ, Laine J, Holmberg C (1997) Methylprednisolone exposure, rather than dose, predicts adrenal suppression and growth inhibition in children with liver and renal transplants. J Clin Endocrinol Metab 82:75-77

31. Seikku P, Raivio T, Janne OA, Neuvonen PJ, Holmberg C (2006) Methylprednisolone exposure in pediatric renal transplant patients. Am J Transplant 6:1451-1458

32. Chavatte C, Guest G, Proust V, Le Bihan C, Gimenez F, Maisin A, Loirat C, Mogenet A, Bresson JL, Hankard R, Broyer M, Niaudet P, Singlas E (2004) Glucocorticoid pharmacokinetics and growth retardation in children with renal transplants. Pediatr Nephrol 19:898-904

33. Pape L, Ehrich JH, Zivicnjak M, Offner G (2005) Growth in children after kidney transplantation with living related donor graft or cadaveric graft. Lancet 366:151-153 
34. Tejani A, Cortes L, Sullivan EK (1996) A longitudinal study of the natural history of growth post-transplantation. Kidney Int 53: S103-108

35. Daughaday WH (2000) Growth hormone axis overviewsomatomedin hypothesis. Pediatr Nephrol 14:537-540

36. Jux C, Leiber K, Hugel U, Blum W, Ohlsson C, Klaus G, Mehls O (1998) Dexamethasone impairs growth hormone (GH)-stimulated growth by suppression of local insulin-like growth factor (IGF)-I production and expression of GH- and IGF-I-receptor in cultured rat chondrocytes. Endocrinology 139:3296-3305

37. Koedam JA, Hoogerbrugge CM, Van Buul-Offers SC (2000) Differential regulation of IGF-binding proteins in rabbit costal chondrocytes by IGF-I and dexamethasone. J Endocrinol 165: $557-567$

38. Jonsson KB, Ljunghall S, Karlström O, Johansson AG, Mallmin $\mathrm{H}$, Ljunggren O (1993) Insulin-like growth factor I enhances the formation of type I collagen in hydrocortisone-treated human osteoblasts. Biosci Rep 13:297-302

39. Clark RG (2005) Recombinant insulin-like growth factor-1 as a therapy for IGF-1 deficiency in renal failure. Pediatr Nephrol 20:290-294

40. Smink JJ, Buchholz IM, Hamers N, van Tilburg CM, Christis C, Sakkers RJ, de Meer K, van Buul-Offers SC, Koedam JA (2003) Short-term glucocorticoid treatment of piglets causes changes in growth plate morphology and angiogenesis. Osteoarthritis Cartilage 11:864-871

41. Chrysis D, Ritzen EM, Savendahl L (2003) Growth retardation induced by dexamethasone is associated with increased apoptosis of the growth plate chondrocytes. J Endocrinol 176:331-337

42. Harmon WE, Jabs K (1992) Factors affecting growth after renal transplantation. J Am Soc Nephrol 2:S295-303

43. Schaefer F, Hamill G, Stanhope R, Preece MA, Schärer K (1991) Pulsatile growth hormone secretion in peripubertal patients with chronic renal failure. Cooperative study group on pubertal development in chronic renal failure. J Pediatr 119:568-577

44. Haffner D, Schaefer F, Girard J, Ritz E, Mehls O (1994) Metabolic clearance of recombinant human growth hormone in health and chronic renal failure. J Clin Invest 93:1163-1171

45. Rabkin R, Sun DF, Chen Y, Tan J, Schaefer F (2005) Growth hormone resistance in uremia, a role for impaired JAK/STAT signaling. Pediatr Nephrol 20:313-318

46. Ulinski T, Mohan S, Kiepe D, Blum WF, Wingen AM, Mehls O, Tönshoff B (2000) Serum insulin-like growth factor binding protein (IGFBP)-4 and IGFBP-5 in children with chronic renal failure: relationship to growth and glomerular filtration rate. The European study group for nutritional treatment of chronic renal failure in childhood. German study group for growth hormone treatment in chronic renal failure. Pediatr Nephrol 14:589-597

47. Tönshoff B, Kiepe D, Ciarmatori S (2005) Growth hormone/ insulin-like growth factor system in children with chronic renal failure. Pediatr Nephrol 20:279-289

48. Kuizon BD, Salusky IB (1999) Growth retardation in children with chronic renal failure. J Bone Miner Res 14:1680-1690

49. Maniar S, Kleinknecht C, Zhou X, Motel V, Yvert JP, Dechaux M (1996) Growth hormone action is blunted by acidosis in experimental uremia or acid load. Clin Nephrol 46:72-76

50. Green J, Maor G (2000) Effect of metabolic acidosis on the growth hormone/IGF-I endocrine axis in skeletal growth centers. Kidney Int 57:2258-2267

51. Carbajo E, Lopez JM, Santos F, Ordonez FA, Nino P, Rodriguez J (2001) Histologic and dynamic changes induced by chronic metabolic acidosis in the rat growth plate. J Am Soc Nephrol 12:1228-1234

52. Koch Nogueira PC, David L, Cochat P (2000) Evolution of secondary hyperparathyroidism after renal transplantation. Pediatr Nephrol 14:342-346
53. Thissen JP, Ketelslegers JM, Underwood LE (1994) Nutritional regulation of the insulin-like growth factors. Endocr Rev 15:80 101

54. VandeHaar MJ, Moats-Staats BM, Davenport ML, Walker JL, Ketelslegers JM, Sharma BK, Tönshoff B (1991) Reduced serum concentrations of insulin-like growth factor-I (IGF-I) in proteinrestricted growing rats are accompanied by reduced IGF-I mRNA levels in liver and skeletal muscle. J Endocrinol 130:305-312

55. Thissen JP, Davenport ML, Pucilowska JB, Miles MV, Underwood LE (1992) Increased serum clearance and degradation of 125Ilabeled IGF-I in protein-restricted rats. Am J Physiol 262:E406411

56. Schaefer F, Veldhuis JD, Robertson WR, Dunger D, Schërer K (1994) Immunoreactive and bioactive luteinizing hormone in pubertal patients with chronic renal failure. Cooperative Study Group on Pubertal Development in Chronic Renal Failure. Kidney Int 45:1465-1476

57. McEnery PT, Gonzalez LL, Martin LW, West CD (1973) Growth and development of children with renal transplants. Use of alternate-day steroid therapy. J Pediatr 83:806-814

58. Broyer M, Guest G, Gagnadoux MF (1992) Growth rate in children receiving alternate-day corticosteroid treatment after kidney transplantation. J Pediatr 120:721-725

59. Jabs K, Sullivan EK, Avner ED, Harmon WE (1996) Alternateday steroid dosing improves growth without adversely affecting graft survival or long-term graft function. A report of the North American pediatric renal transplant cooperative study. Transplantation 61:31-36

60. Ferraris JR, Pasqualini T, Legal S, Sorroche P, Galich AM, Pennisi P, Domene H, Jasper H (2000) Effect of deflazacort versus methylprednisone on growth, body composition, lipid profile, and bone mass after renal transplantation. The deflazacort study group. Pediatr Nephrol 14:682-688

61. Klare B, Strom TM, Hahn H, Engelsberger I, Meusel E, Illner WD, Abendroth D, Land W (1991) Remarkable long-term prognosis and excellent growth in kidney-transplant children under cyclosporine monotherapy. Transplant Proc 23:1013-1017

62. Ellis D (2000) Growth and renal function after steroid-free tacrolimus-based immunosuppression in children with renal transplants. Pediatr Nephrol 14:689-694

63. Hocker B, John U, Plank C, Wuhl E, Weber LT, Misselwitz J, Rascher W, Mehls O, Tönshoff B (2004) Successful withdrawal of steroids in pediatric renal transplant recipients receiving cyclosporine A and mycophenolate mofetil treatment: results after four years. Transplantation 78:228-234

64. Sarwal MM, Vidhun JR, Alexander SR, Satterwhite T, Millan M, Salvatierra O Jr (2003) Continued superior outcomes with modification and lengthened follow-up of a steroid-avoidance pilot with extended daclizumab induction in pediatric renal transplantation. Transplantation 76:1331-1339

65. Kovàcs G, Fine RN, Worgall S, Schaefer F, Hunziker EB, Mehls O (1991) Recombinant human growth hormone overcomes the growth-suppressive effect ofmethylprednisolone in uraemic rats. Pediatr Nephrol 5:552-555

66. Tönshoff B, Mehls O (1997) Factors affecting growth and strategies for treatment in children after renal transplantation. Pediatr Transplant 1:176-182

67. Hokken-Koelega AC, Stijnen T, de Jong RC, Donckerwolcke RA, Groothoff JW, Wolff ED, Blum WF, de Muinck Keizer-Schrama SM, Drop SL (1996) A placebo-controlled, double-blind trial of growth hormone treatment in prepubertal children after renal transplant. Kidney Int 53:S128-134

68. Maxwell H, Rees L (1998) Randomised controlled trial of recombinant human growth hormone in prepubertal and pubertal renal transplant recipients. British association for pediatric nephrology. Arch Dis Child 79:481-487 
69. Guest G, Bérard E, Crosnier H, Chevallier T, Rappaport R, Broyer M (1998) Effects of growth hormone in short children after renal transplantation. French society of pediatric nephrology. Pediatr Nephrol 12:437-446

70. Fine RN, Stablein D, Cohen AH, Tejani A, Kohaut E (2002) Recombinant human growth hormone post-renal transplantation in children: a randomized controlled study of the NAPRTCS. Kidney Int 62:688-696

71. Tydén G, Berg U, Reinholt F (1990) Acute renal graft rejection after treatment with human growth hormone. Lancet 336:14551456

72. Maxwell H, Nair DR, Dalton RN, Rigden SP, Rees L (1995) Differential effects of recombinant human growth hormone on glomerular filtration rate and renal plasma flow in chronic renal failure. Pediatr Nephrol 9:458-463

73. Chavers BM, Doherty L, Nevins TE, Cook M, Sane K (1995) Effects of growth hormone on kidney function in pediatric transplant recipients. Pediatr Nephrol 9:176-181

74. Fine RN, Stablein D (2005) Long-term use of recombinant human growth hormone in pediatric allograft recipients: a report of the NAPRTCS Transplant Registry. Pediatr Nephrol 20:404-408

75. Snow EC, Felldbush TL, Oaks JA (1981) The effect of growth hormone and insulin upon MLC responses and the generation of cytotoxic lymphocytes. J Immunol 126:161-164

76. Benfield MR, Kohaut EC (1997) Growth hormone is safe in children after renal transplantation. J Pediatr 131:S28-31

77. Maxwell H, Amlot P, Rees L (2000) Growth hormone and markers of immune function in children with renal transplants. Pediatr Nephrol 14:473-475

78. Dharnidharka V, Talley L, Stablein D, Fine RN (2007) Recombinant human growth hormone $(\mathrm{rhGH})$ use pretransplant and risk of lymphoproliferative disease (LPD) post transplant (abstract no. 35). Pediatr Transplant 11[Suppl1]:43

79. Tydén G, Wernersson A, Sandberg J, Berg U (2000) Development of renal cell carcinoma in living donor kidney grafts. Transplantation 70:1650-1656

80. Mehls O, Wilton P, Lilien M, Berg U, Broyer M, Rizzoni G, Waldherr R, Opelz G (2002) Does growth hormone treatment affect the risk of post-transplant renal cancer? Pediatr Nephrol 17:984-989
81. Filler G, Amendt P, Kohnert KD, Devaux S, Ehrich JH (1998) Glucose tolerance and insulin secretion in children before and during recombinant growth hormone treatment. Horm Res 50:32-37

82. Ghio L, Damiani B, Garavaglia R, Oppizzi G, Taioli E, Edefonti A (2002) Lipid profile during rhGH therapy in pediatric renal transplant patients. Pediatr Transplant 6:127-131

83. Querfeld U, Dopper S, Gradehand A, Kiencke P, Wahn F, Zeisel HJ (1999) Long-term treatment with growth hormone has no persisting effect on lipoprotein (a) in patients with Turner's syndrome. J Clin Endocrinol Metab 84:967-970

84. Sanchez CP, He YZ (2005) Daily or intermittent calcitriol administration during growth hormone therapy in rats with renal failure and advanced secondary hyperparathyroidism. J Am Soc Nephrol 16:929-938

85. Koller EA, Stadel BV, Malozowski SN (1997) Papilledema in 15 renally compromised patients treated with growth hormone. Pediatr Nephrol 11:451-454

86. Gharib H, Cook DM, Saenger PH, Bengtsson BA, Feld S, Nippoldt TB, Rodbard HW, Seibel JA, Vance ML, Zimmerman D, Palumbo PJ, Bergman DA, Garber JR, Hamilton CR Jr, Petak SM, Rettinger HI, Service FJ, Shankar TP, Stoffer SS, Tourletot JB, American Association of Clinical Endocrinologists Growth Hormone Task Force (2003) American Association of Clinical Endocrinologists medical guidelines for clinical practice for growth hormone use in adults and children-2003 update. Endocr Pract 9:64-76

87. National Kidney Foundation (NKF) (2005) K/DOQI Clinical Practice Guidelines for bone metabolism and disease in children with chronic kidney disease. Available at: http://www.kidney.org/professionals/ KDOQI/guidelines_pedbone/guide11.htm. Accessed 1 June 12007

\section{Answers:}

1) $\mathrm{c}$

2) $b$

3) $\mathrm{b}$

4) $\mathrm{e}$

5) d 